\title{
O QUE É OPINIÃO PÚBLICA? ESTUDO DE HISTÓRIA CONSTITUCIONAL BRASILEIRA
}

Judá Leão Lobo ${ }^{1}$

\begin{abstract}
Necessary to instruction - to excitation - in a word to a state of preparation directed to this purpose, is - (who does not see it?) the perfectly unrestrained communication of ideas on every subject within the field of government: the communication, by vehicles of all sorts - by signs of all sorts: signs to the ear - signs to the eye - by spoken language - by written, including printed, language - by the liberty of the tongue, by the liberty of the writing desk, by the liberty of the post office - by the liberty of the press.
\end{abstract}

Jeremy Bentham

\begin{abstract}
Resumo
À luz da história constitucional, este ensaio pretende resolver o seguinte problema: o que é opinião pública? Pela análise de evidências históricas, chega a solução relevante tanto à teoria quanto à história das constituições políticas, sem menosprezar a complexidade da monarquia constitucional brasileira. Recepcionada nesse contexto, a opinião pública incorporava características de uma sensibilidade jurídica particular, em que a legalidade contrastava com deveres morais (caridade, perdão, benevolência) provenientes da tradição religiosa.
\end{abstract}

Palavras-chave: Opinião Pública; Responsabilidade Moral; Constituição Política; História Constitucional; Monarquia Constitucional Brasileira.

\section{INTRODUÇÃO}

Entre os juristas, a experiência constitucional brasileira é pouco conhecida fora dos velhos modelos, centrados em textos constitucionais e visões pré-concebidas do movimento da história. Como observa Christian Lynch, "Do atraso brasileiro em matéria de história político-constitucional não se pode mais alegar que reflita sua condição 'atrasada' e 'periférica'". E acrescenta, "em matéria de história constitucional, países como Portugal, a Espanha, o Chile e a Argentina parecem quilômetros à nossa frente" (LYNCH, 2014, p. 13). O vazio se perpetua por certa indolência ante pesquisas substanciais, assim como pela inclinação a autoridade e repetição fácil, em

\footnotetext{
${ }^{1}$ Doutorando pelo Programa de Pós-Graduação em Direito da Universidade Federal do Paraná, no qual está vinculado ao núcleo História, Direito e Subjetividade. Editor-adjunto da Revista da Faculdade de Direito UFPR. Professor de teoria e história do direito na Universidade Positivo. E-mail: juda.lobo@up.edu.br
} 
detrimento de argumento e reflexão crítica.

A monarquia constitucional talvez seja o período mais prejudicado. Se as tradicionais análises centradas no texto da Constituição de 1824 ignoram o viés dinâmico das constituições políticas do séc. XIX, a hierarquia preconcebida entre monarquia e república distorce a compreensão do passado. Sob os falsos signos do atraso, do despotismo e da centralização absoluta, a cultura jurídica do período permanece no esquecimento. Cumpre investigar, assim, sua densidade moral e política. E isso a partir do problema o que é opinião pública?, capaz de trazer à luz não apenas a complexidade do período; também contribuições relevantes a teoria e história constitucional.

Esse não é um problema simples. No século das constituições políticas, opinião pública raramente merece tratamento particular por parte de autores de livros e colunas de jornal, embora seja empregada aqui e ali com frequência suficiente para despertar a curiosidade. Do ponto de vista historiográfico, assim, uma solução adequada exige o resgate, a partir dos detalhes sintomáticos contidos em fontes históricas, do que veio a se revelar no decorrer da pesquisa um dos alicerces das constituições políticas. Para recompor o mosaico da opinião pública, fez-se necessário recolher ladrilhos dispersos nos escombros da história.

Este artigo consiste, nessa linha, na exposição dos resultados mais gerais obtidos em uma pesquisa indiciária (GINZBURG, 1989), cujo problema inicial era muito distinto. A pretensão consistia, de início, em investigar de que forma umas fraudes eleitorais particularmente indiscretas estariam relacionadas ao fechamento de um número elevado de escolas na Província do Paraná, gerando protestos entre professores e população. Para tanto, foram investigadas as principais gazetas partidárias circulantes em Curitiba, Gazeta Paranaense (partido conservador), Dezenove de Dezembro (partido liberal) e A Republica (partido republicano), durante 1888 - ano de ambos os acontecimentos visados.

No decorrer da leitura de edição após edição, assim como de obras jurídicas relevantes para o momento, a expressão opinião pública surgia sem maiores explicações, com uma frequência intrigante. A dúvida cresceu progressivamente, tornando-se um novo problema somente ao final da investigação das fontes, como frequentemente ocorre em pequisas historiográficas. Apenas então o foco se voltou a uma questão conceitual e à busca por significados em autores da época, dentre os quais somente Bentham trazia uma definição sistemática. Partindo da micro história, portanto, a pesquisa deslocou-se à noção de opinião pública, momento em que o recurso às fontes bibliográficas trouxe maior refinamento teórico ao arcabouço indiciário recolhido na discussão da imprensa. Esse arcabouço, no entanto, demostrou que refinamento teórico consistia também na redução da complexidade político-jurídica da opinião pública. Isso fica particularmente claro no ponto 2.2.

A associação de fontes eruditas e cotidianas da cultura jurídica (LOBO; STAUT JÚNIOR, 2015) marca a metodologia deste estudo. Do encontro entre "alta" e "baixa" cultura jurídica, surge a força argumentativa de uma narrativa não estruturada de forma linear, e sim como progressivo entretecer de fundamentos historiográficos. 
Tendo em vista a trajetória particular da pesquisa em que surgiu o problema o que é opinião pública?, não deveria ser diferente a forma de expor a solução e as conclusões encontradas. Não se trata, portanto, de uma resposta que passa por caminho conceitual para chegar a uma definição. Pelo contrário, ela se vale de um arcabouço indiciário para atingi-la.

Mas esses indícios centrados em Curitiba ainda seriam relevantes perante um problema tão amplo quanto o proposto? Essa eventual preocupação funda-se na ideia equivocada de que haveria "locais gerais" por excelência. Além de conterem detalhes particulares à realidade local, as fontes curitibanas podem ser consideradas testemunhos confiáveis da cultura jurídica brasileira do séc. XIX, seja pela formação jurídica comum centrada nas Faculdades de Direito de S. Paulo e Recife, seja pela intensa circularidade de cargos voltada ao treinamento da elite política imperial (CARVALHO, 2012, p. 145-168).

Por sua posição fronteiriça se comparada à da corte ou à dos grandes centros econômicos, a imprensa política curitibana pode ser considerada mais significativa das continuidades com passado e tradição. $O$ verniz modernizante, afinal, apresentava-se mais tênue na margem do que no centro, onde os valores fundantes da cultura jurídica brasileira nem sempre ficavam tão evidentes como na capital de uma província periférica do Império. Antes de ser duvidosa, a capacidade de a imprensa política curitibana testemunhar sobre o problema proposto é reforçada por sua posição fronteiriça, uma vez que a força da opinião pública na monarquia constitucional brasileira provinha em grande parte das continuidades com o passado, como sustento no decorrer do texto.

Alguns argumentos expostos neste trabalho, ademais, careceriam de fundamentação historiográfica mais densa: a fisionomia moral do homem público, a força da imprensa na política constitucional, a tensão entre legalidade e moralidade, a existência de fluxos nacionais de opinião pública. Para deixar pouca margem a dúvidas lógico-hipotéticas nesses casos, seriam necessárias mais páginas do que as recomendadas para um artigo científico. Outros virão na sequência, com o intuito de comprovar especificamente aspectos que, neste, só puderam ser levantados de passagem. Convém não esquecer, portanto, estar este trabalho respaldado em pesquisa mais ampla. Ele pretende expô-la apenas no que for relevante para responder ao problema o que é opinião pública?, evitando aprofundar aspectos secundários e fugir à linha proposta. Daí a presença marcante de fontes bibliográficas ao longo do texto.

Quanto à estrutura, por fim, esta exposição centra-se em duas partes. Mantendo-se relativamente fiel à trajetória da pesquisa, num primeiro momento a narrativa parte de detalhes da Curitiba de fins do Império, depreendendo gradualmente as feições da opinião pública como uma categoria ${ }^{2}$ constitucional. Ao inseri-la no âmbito do constitucionalismo do séc. XIX, analiso a posição basilar por ela ocupada no âmbito política 
constitucional, assim como a duplicidade que era inerente à opinião pública: estabilidade ou transformação? Num segundo momento, parto da metáfora Tribunal da Opinião Pública (Bentham) no intuito de analisar sua recepção ${ }^{3}$ tanto no pensamento quanto no cotidiano constitucional brasileiro. Essa análise "por camadas" da cultura jurídica permite apreender a complexidade do período analisado. Ao adquirir concretude, a opinião pública adaptava-se à sensibilidade jurídica brasileira (GEERTZ, 2013, p. 169-238), gerando figuraçõest particulares. A categoria pertencente ao ideário liberal era animada, aqui, por um espírito de antigo regime.

\section{ASPECTOS DE UMA CATEGORIA DA POLÍTICA CONSTITUCIONAL}

Encarnada nos órgãos da imprensa políticaś, a opinião local sintetizava as distintas sensibilidades vivenciadas no cotidiano, contendo complexidade peculiar a deixar-se apreender apenas na leitura de número após número dos periódicos em discussão. Embora o foco das folhas analisadas fosse o espaço das decisões e atos públicos, era inevitável trazerem à publicidade temas e representações da vida cotidiana, dos epitáfios lamentando a perda de personagens importantes às recepções de amigos, familiares e homens públicos na estação da estrada de ferro, ao som de bandas de música habituadas a competir com o estrugir de foguetes e girândolas; da ordem do chefe de polícia proibindo o entrudo nos dias de carnaval ao elogio dos bailes no salão do Clube Curitibano, organizados nos mesmos dias; dos discursos proferidos por bacharéis e autodidatas eloquentes das janelas das casas, tipografias e órgãos públicos aos profusos copos-d'água $a^{6}$ proporcionados em ocasiões especiais, muitas vezes com libertações graciosas de escravos ou protestos políticos.

A opinião pública provincial revelava encontros simbólicos inusitados, expressando a sobreposição, num mesmo tempo e espaço, de modos de vida e concepções pertencentes a épocas e contextos teoricamente distintos. Ao lado de cabras de boa raça - e muito leiteiras! - (Dezenove de Dezembro, Curityba, 15 dez. de 1888, p. 3), anunciavam-se espetáculos de prestidigitadores no teatro S. Theodoro, hoje Guaíra, que vinham apresentar ao público agreste as últimas modas, tendências e maravilhas da Europa, dentre elas a técnica da hipnose (Dezenove de Dezembro, Curityba, $1^{\circ}$ ago. de 1888, p. 4). Ao sair do passeio público, espécie de jardim inglês em que a natureza dominada serve de ambiente à publicidade, o flâneur aristocrático, trajado à francesa graças a bom

\footnotetext{
${ }^{2}$ Nesse sentido, são entidades discursivas que têm "capacidade de criar conhecimento (se não - adianto já toda a provocação - de criar realidade)", possuindo natureza "activamente organizadora". (HESPANHA, 2010, p. 13, 14 e 15).

${ }^{3}$ Cf. Segundo Hespanha, "receber um texto (tomada a palavra no seu sentido mais vasto) é (re)produzil-o, dando-lhe um novo significado, de acordo com a nova maneira como ele é integrado no universo intelectual (e emocional) do leitor." (HESPANHA, 2005, p. 40).

${ }^{4}$ A realidade social é composta por indivíduos, e as individualidades se conformam em redes de interdependência: "É esse o caso quando falamos que homens singulares formam entre si figurações de tipos diversos, ou que as sociedades não são nada mais que figurações de homens interdependentes." (ELIAS, 1994, p. 43).

${ }^{5}$ A dicotomia entre imprensa política e literária correspondia àquela entre cidadania ativa e passiva.

${ }^{6}$ Termo designando as recepções com doces e licores, especialmente em atos solenes.
} 
cargo público, seria levado pelo circuito de sua proménade à Rua da Imperatriz $7^{7}$, onde o matte é enorme em algumas valetas", razão pela qual manifestaria sua opinião baseada na teoria dos miasmas, a fim de alertar a câmara municipal do risco à saúde pública (A Republica, Curityba, 24. Set. de 1888, p.3).

Às discussões mais acaloradas em torno da política constitucional, justapunham-se figuras folclóricas sobreviventes na memória do colaborador anônimo e transmitidas pelo papel familiar da avó, que, "arregalando os olhos", dizia ao netinho, "Olhe, si você continúa a fazer isto eu chamo o tutú, q' esta alli naquelle quarto fechado"; ou fingia ordenar a alguém da casa, "vae dizer lá na rua ao Papão que venha buscar este menino" (Gazeta Paranaense, Curityba, 25 dez. de 1888, p. 1). Ecos do passado e da tradição reverberavam na esfera de publicidade, não limitada a espaços letrados e meios escritos. Ao emergirem as boas polêmicas, grande parte da inquietação manifestava-se "pelas tavernas e armazens, lugares onde mais se discute a politica do paiz, de involta com as murmurações da vida alheia" (A Republica, Curityba, 14 dez. de 1888, p. 1).

O meio sistemático e diário de exprimir a inquietação política, no entanto, era a imprensa periódica, espécie de ponto de encontro entre cafés, tavernas e armazéns, de um lado, e, de outro, tribuna parlamentar, atos do governo e programas partidários. Tratava-se de uma das instituições mais bem organizadas e poderosas tanto no país quanto na província. Não surpreendia, assim, que na biblioteca pública provincial fosse "superior a sessenta o numero de jornaes com pontualidade e graciosamente remettidos á Biblioteca pelas respectivas Redações, figurando entre elles todos os que se publicão na Provincia e os mais importantes do Imperio", conforme o relatório da presidência da província do Paraná, referente ao ano de 1887 (Gazeta Paranaense, Curityba, 19 mai. de 1888,p. 1).

Se a opinião pública não se limitava a dar publicidade à política constitucional, também não se afastava dela. Nos debates faziam-se sentir tanto equilíbrios locais quanto gerais da política constitucional. A perspectiva de ascensão de novo gabinete composto por membros da oposição em sistema bipartidário, sempre possível pelo exercício das atribuições constitucionais do poder moderador ${ }^{8}$, mantinha viva e efervescente a disputa política tanto na Corte quanto nas províncias. A composição de novo ministério, se elevasse a oposição ao governo, significava a nomeação de novos presidentes de província, que, por sua vez, renovavam os funcionalismos provinciais por meio de nomeações agradáveis a seu partido, garantindo-lhe fidelidades e vantagens eleitorais. Em sociedade economicamente pouco dinâmica, o emprego público gerava dependências por ser das poucas fontes de renda disponíveis . Era "a profissão nobre e a vocação de todos", na sentença de Joaquim Nabuco (2000, p.

\footnotetext{
${ }^{7}$ Renomeada Rua XV de novembro após a proclamação da república.

${ }^{8}$ Art. 101 da Constituição de 1824: "O Imperador exerce o Poder Moderador: [...] V - Nomeando, e demittindo livremente os Ministros de Estado. [...]." O Decreto n. 526, de 20 de julho de 1847, que criou a figura do presidente do conselho de ministros. Desde então, o poder moderador nomeava apenas o presidente do conselho, cuja função era nomear os demais ministros e atuar como chefe de governo.

${ }^{9}$ Sobre a visão positiva da disputa política imperial, cf. CARVALHO, 2012. Sobre os efeitos negativos da alternância política sobre a estabilidade burocrática, cf. HOLANDA, 2005.
} 
128).

Decorrentes de disputa política e dependência do estado, ambas associadas ao que Carlos Petit (2000) denominou perfil eloquente do jurista (orador, jornalista, homem público), as tensões a perpassar a arena da política constitucional geravam uma opinião particularmente intensa e combativa. Ao serem discutidos em manifestações diárias, imprensa e parlamento, os atos expunham-se ao juízo da opinião pública. Representantes e funcionários seriam responsabilizados legal e, sobretudo, moralmente. Nesse caso, a responsabilidade assumiria a forma de censura imputada à reputação por meio da discussão pública. As gazetas sintetizavam ideias e opiniões circulantes no parlamento, em meetings, nos armazéns e tavernas, constituindo-se em espaço privilegiado de formação da cultura jurídica. Ao expor no cotidiano atos e decisões dos poderes constituídos, a imprensa tornavase instituição basilar ao às constituições do séc. XIX (LOBO; PEREIRA, 2014, p. 179-206), encarnando diariamente seu apelo à responsabilidade dos governantes pela publicidade de seus atos.

\section{Publicidade e responsabilidade: os pilares constitucionais da opinião pública}

Se as constituições políticas se caracterizavam por estabelecer sistemas baseados na liberdade dos modernos, conceito trabalhado por Benjamin Constant em discurso proferido no Ateneu Real de Paris ${ }^{10}$, também garantiam liberdades voltadas à interferência nos negócios públicos. Presente no penúltimo parágrafo da transcrição, a ideia de que o desafio consistia em combinar formas diretas e indiretas de participação por meio da opinião pública mostra ser inadequada uma leitura meramente representativa do constitucionalismo do séc. XIX. Uma vez constituídas as instituições públicas, sublinhava Constant, deveriam "consagrar a influência dos cidadãos sobre a coisa pública, chamá-los a participar, por meio de suas determinações e preferências, do exercício do poder, garantir-lhes um direito de controle e supervisão pela manifestação de suas opiniões (...."11.

Político e dinâmico, esse constitucionalismo visava a estruturar uma arena político-constitucional vinculada à atuação vigilante da opinião pública. Para os teóricos do período, "a constituição é certamente a norma suprema, mas tal norma possui natureza essencialmente política" (FIORAVANTI, 2009, p. 38) ${ }^{12}$, afastando-se do viés normativo atribuído às constituições atuais. Inclusão e garantia de direitos ocorriam "no plano do programa

\footnotetext{
10 CONSTANT, Benjamin. De la liberté des anciens comparée à celle des modernes. Disponível em: « http://www.panarchy.org/constant/liberte.1819.html». Acesso em: «01/08/2014».

11 "(...) elles doivent pourtant consacrer leur influence sur la chose publique, les appeler à concourir, par leurs déterminations et par leurs suffrages, à l'exercice du pouvoir, leur garantir un droit de contrôle et de surveillance par la manifestation de leurs opinions (...)." (Tradução livre.Idem, Ibdem).

12 "(...) la costituzione è certamente la norma suprema, ma tale norma ha uma natura essenzialmente politica, esprimendosi in essa il grande patto fra la monarchia e la nazione, dalla cui stabilità tutto dipende, compresa la garanzia dei diritti." (Tradução livre).
} vol.10, nº. 01, Rio de Janeiro, 2017.pp. 494-518 
político, da maturação da sociedade e da opinião publica, não no plano normativo" (FIORAVANTI, p. 39) ${ }^{13}$. Bentham considerava fundamental, por isso, tornar manifesto quão essenciais "aquelas duas liberdades intimamente conexas - a liberdade de imprensa e a liberdade de discussão pública por via oral - são para qualquer coisa que possa, com alguma propriedade, ser nomeada bom governo" (BENTHAM, 1821, p. IV) ${ }^{14}$. Isso se aplicava às demais garantias à manifestação da opinião pública, a operar "como freio à conduta da minoria governante" (BENTHAM, 1821, p. 12) ${ }^{15}$ pela publicidade de seus atos, tornando-os discutíveis e, seus agentes, responsáveis pelas decisões adotadas.

Não surpreende, portanto, Silvestre Pinheiro Ferreira (1837, p. VIII) ${ }^{16}$ resumir os sistemas constitucionais do séc. XIX em dois axiomas: "Independencia e eleição nacional, para todos os poderes" e "Responsabilidade e publicidade de todos os actos". Em outros termos, assentava-os em quatro pilares: não apenas em sistema representativo e separação dos poderes; também na opinião pública, ou seja, responsabilidade pela publicidade. Esses pilares constitucionais amparavam-se mutuamente na busca por harmonia dos arranjos institucionais e estabilidade do processo político. Conjugando dois deles, a opinião pública procurava tanto evitar os abusos dos poderes constituídos quanto vincular os representantes às demandas dos representados.

Pimenta Bueno, o Marquês de São Vicente, analisava a Constituição do Império à luz desse ideário constitucional. Ao discorrer sobre os debates legislativos, esclarecia, "Desta marcha reflectida [três discussões em cada casa], destes differentes gráos de instrucção, resulta não só a illustração da materia, como a madureza da deliberação. É marcha que dá tempo á imprensa, á opinião publica para manifestar-se" (PIMENTA BUENO, 1857, p. 133 $)^{17}$. O processo legislativo teria sido concebido de forma a permitir intervenção nos debates parlamentares, o que vinculava a esfera de atuação do legislador à sociedade politicamente organizada. Ao exercer a faculdade de sanção, ademais, nem o poder moderador seria independente da opinião pública. "Em verdade, quando tres legislaturas pedem a adopção de um projecto reconsiderado tantas vezes em repetidas discussões, (...), quando a opinião publica assim insta, pois sem ella não é possivel persistir nessa solicitação, deve concluir-se que a medida é util" (PIMENTA BUENO, 1857, p. 144-145), afastando-se a eventual denegação, de natureza

\footnotetext{
13 "Certo, quei liberali associavano sempre più la costituzione anche ai diritti e alle liberta, ma sul piano del programma político, della maturazione della società e della pubblica opinione, e non sul piano normativo, dell'opponibilità della costituzione come norma di garanzia, proprio in nome dei diritti violati, alla stessa legge." (Tradução livre).

14 "That object was - the rendering it manifest, how indispensable, at all times and every where, those two intimately-connected liberties - the liberty of the press, and the liberty of public discussion by word of mouth - are to every thing that can, with any propriety, be termed good government." (Tradução livre).

15 "(...) operates as a check upon the conduct of the ruling few ( ... )." (Tradução livre).

${ }^{16}$ Trata-se de jurista português relevante para o pensamento constitucional luso-americano, especialmente para o chamado vintismo português, movimento de efervescência política que influenciaria a constituição brasileira de 1824, adotada com poucas alterações na antiga metrópole em 1826.

${ }^{17}$ No trecho grifado, note-se a coincidência entre opinião pública e imprensa.
} 
meramente suspensiva ${ }^{18}$.

A opinião aproximava os poderes constituídos da sociedade politicamente organizada por diferentes meios de manifestação, nem todos dependentes das eleições. Isso fica claro numa frase de São Vicente, "Em um paiz livre, que tem os recursos da imprensa, o direito de petição, a faculdade eleitoral, o poder da tribuna, é mais que difficil conceber perigos ou oppressão tal que estabeleção uma collisão extrema" (PIMENTA BUENO, 1857, p. 420). Embora não esgote as possibilidades, a enumeração serve ao propósito de relativizar a leitura meramente representativa do constitucionalismo do séc. XIX, em que a faculdade eleitoral consistia talvez no meio mais solene, mas não no mais importante de manifestar a opinião pública. Destacavam-se sobretudo as formas diárias de participação. "A publicidade", afinal, "anima as discussões, enfraquece os preconceitos, as intrigas, os empenhos", constituindo-se em elemento basilar das constituições políticas ao fazer com que "erros e abusos [sejam] bem percebidos e expostos com energia á reprovação" (PIMENTA BUENO, 1857, p. 338).

As constituições do séc. XIX, assim, não se resumiam a simples regramento dos poderes constituídos, nem a mero estabelecimento de eleições periódicas. $\mathrm{O}$ apelo à responsabilidade pela publicidade as constituía, revelando a importância, ao movimento harmônico do processo político-constitucional, da vigilância realizada pela opinião pública. A salvaguarda de direitos e liberdades voltados à discussão pública garantia participação dinâmica à cidadania, assegurando meios de intervenção em e de manifestação sobre atos dos governantes. Por meio de seus pilares constitucionais, a opinião não apenas reforçava o vínculo entre representantes e representados, influindo no sistema representativo; também estabelecia limite aos poderes constituídos, concorrendo à separação dos poderes. Ao aproximar poderes e representantes da sociedade politicamente organizada, portanto, os distintos meios de manifestação, se evitariam colisões extremas, possibilitariam reformas (mais ou menos) graduais.

\section{Estabilidade ou transformação? A duplicidade da opinião pública}

Se o constitucionalismo do séc. XIX não se limitava a meios indiretos de participação, também não cultivava a democracia. Os espaços oficiais de cidadania eram restritos a indivíduos qualificados ao exercício de direitos políticos. A cidadania ativa limitava-se a minorias letradas, proprietárias ou elites burocráticas integradas por ambos os grupos, como no caso do Brasil imperial. As constituições políticas caracterizavam-se pela limitação da soberania (CONSTANT, 1872, p. 16.), ao conceber mecanismos institucionais voltados tanto a limitar o poder (e.g. o delineamento bicameral do legislativo e a submissão de suas deliberações ao poder de veto) quanto a

\footnotetext{
${ }^{18}$ Sobre a proposição o poder moderador é o supremo do Estado, afirmava Zacarias de Góes e Vasconcelos (1978, p. 167) estar "longe de ser verdadeira [...]; porque, segundo a Constituição, aquele dos quatro poderes por ela reconhecidos, que, relativamente aos demais, se deve considerar supremo por excelência, é o legislativo". E acrescentava, "ninguém reúne tantos elementos de
} vol.10, no. 01, Rio de Janeiro, 2017.pp. 494-518 
restringir participação e demandas populares (e.g. o censo baseado em renda ou ilustração, e, no caso das demandas, o citado bicameralismo).

Para Constant, a limitação dos excessos populares seria garantida, "primeiro, pela força que garante todas as verdades reconhecidas, pela opinião: depois, de maneira mais precisa, pela distribuição e equilíbrio dos poderes"19 $^{\prime 1}$ (CONSTANT, 1872, p. 16. O argumento de que a opinião pública consistia em mecanismo de restrição da soberania, entretanto, poderia conduzir a equívocos. Em Principes de politique, o autor baseava-se na Carta de $1814^{20}$, buscando não apenas dar-lhe feições menos absolutistas; também justificar a centralidade do monarca, designando-a poder real ou neutro ${ }^{21}$. Conferindo ao termo aquele matiz popular tão temido em seu tempo, o teórico da restauração em França omitia a duplicidade inerente à opinião pública: tanto limite ao poder quanto abertura a novas demandas.

"O sistema representativo repele a soberania inquieta e turbulenta da escola de Rousseau, da mesma forma que não aceita a que se encarna nos poderes delegados", resumia com precisão Zacarias de Góes e Vasconcelos. E acrescentava, "o regime representativo, reconhecendo o direito de governar na inteligência, assinala ao poder uma posição de superioridade, sem eximi-lo da necessidade de constantemente atender à opinião pública". A fim de assegurar a felicidade do país por meio de boa legislação e administração, submetia-se ao "dever de prestar atenção e acolhimento à voz da opinião pública, não debalde chamada rainha do mundo, em ordem a não perder a mínima parcela de luz". A simples limitação dos poderes seria insuficiente, pois, "por melhor organizado[s] que seja[m], não resume[m] toda a sabedoria da nação" (VASCONCELOS, 1862, p. 83-84).

Abstraídos os contextos particulares, entre Constant, Zacarias de Góes e outros predominava "o intuito de concluir a época das revoluções, de iniciar uma era de progresso gradual, de certeza das possessões, de estabilidade das soluções políticas e institucionais" (FIORAVANTI, 2009, p.35) 22. Desse intuito decorria a divisão da cidadania em ativa e passiva, com exclusão de muitos nacionais ${ }^{23}$ (sobretudo pobres e analfabetos) da alta

soberania como o Imperador, mas dentre os poderes políticos o primeiro e principal é sempre o poder legislativo, que lhe é delegado e à Assembléia Geral."

19 "La limitation de la souveraineté est donc véritable, et elle est possible. Elle sera garantie d'abord par la force qui garantit toutes les vérités reconnues, par l'opinion: ensuite elle le sera d'une manière plus précise, par la distribution et par la balance des pouvoirs." (Tradução livre).

20 A Carta Constitucional de 1814 está disponível na íntegra em: «http://www.conseil-constitutionnel.fr/conseilconstitutionnel/francais/la-constitution/les-constitutions-de-la-france/charte-constitutionnelle-du-4-juin-1814.5102.html».

${ }^{21}$ A Carta de 1814 não instituía o poder real ou neutro. A elaboração sistemática de um poder moderador, com atribuições taxativas, é característica das Constituições de 1824 (brasileira) e de 1826 (portuguesa). O comentário de Silvestre Pinheiro Ferreira é ilustrativo nesse sentido: "en nuestra opinion los redactores de las dos constituciones brasilera y portuguesa merecen grandes elojios por haver desenvuelto, en el capitulo del poder moderador, nociones que en vano se buscaria en otra parte." (FERREIRA, s/d, p. 82).

22 "In quell'universo prevale il desiderio di chiudere l'epoca delle rivoluzioni, di aprire un'età di progresso graduale, di certezza dei possessi, di stabilità delle soluzioni politiche e istituzionali." (Tradução livre).

${ }^{23}$ Durante todo o séc. XIX e parte do XX, além de censitário, o voto era típico da população masculina (livre, nos países com escravidão). Por mais radical, não houve governo disposto a ampliar a capacidade política à população feminina, embora houvesse demandas nesse sentido. 
política constitucional. Marcados de incapacidade política, aos cidadãos passivos restavam os direitos e liberdades civis, atribuídos a todos e cuja garantia (agora sim) dependia da estabilidade da política constitucional, em cujo âmbito estariam impedidos de influir. A maioria dependeria, assim, do desinteresse de elites letradas ou proprietárias...

Em Direito publico brazileiro, São Vicente associava a opinião pública a meios de manifestação vinculados à capacidade política. "A liberdade politica, a imprensa, o direito de petição ou reclamação politica, e sobretudo a tribuna, é quem vem apoiar e proteger a liberdade civil, a vida moral dos individuos" (PIMENTA BUENO, 1857, p. 468). O direito de petição, por exemplo, era definido como "a faculdade legitima que o cidadão activo tem de apresentar por escripto aos poderes publicos suas opiniões, suas idéas, interesses que partilha e seus votos sobre os negocios sociaes de legislação ou da administração do Estado", sendo "antes um direito politico do que natural ou individual" e, nesse sentido, "quase semelhante ao da liberdade da imprensa politica, uma especie de intervenção no governo do paiz" (PIMENTA BUENO, 1857, p. 434).

Embora Pimenta Bueno (1857, p. 435) mencionasse espaços mais inclusivos ("toda manifestação pacifica, moral, regular de sua opinião [do povo], não póde deixar de ser um direito; é mesmo um signal do interesse que elle toma pela materia e causa publica"), havia elaborado síntese teórica caracterizada pelo apego a modelos teóricos, se não carentes de fundamento, ao menos distantes do cotidiano constitucional. Do exercício da faculdade eleitoral às discussões em armazéns e esquinas, a opinião pública constituía-se num complexo de figurações político-constitucionais, boa parte delas não redutível aos limites eruditos da cultura jurídica. Se a divisão entre liberdade civil e política aplicava-se ao direito de votar e ser votado, mitigava-se no exercício de direitos e liberdades destinados à manifestação da opinião pública, especialmente no cotidiano constitucional.

Se o exercício do voto feminino estava fora de questão, assim como a elegibilidade do belo sexo, sua possibilidade de publicar artigos em jornais era menos questionável, sobretudo no caso da imprensa literária ${ }^{24}$. A possibilidade de participação seria tanto mais ampla quanto menos formal o espaço público. Em artigo que relatava conferência republicana realizada na Lapa, o autor informava ter permanecido "encostado à janella, ouvindo umas meninas cantarem a Marselheza" (A Republica, Curityba, 29 dez. de 1888, p. 2). Tratava-se da manifestação pública de uma opinião política contrária aos poderes constituídos, em que tinha voz coro feminino a cantar o hino republicano. Indício da ampla liberdade de expressão existente, o testemunho indica a permeabilidade de alguns espaços de opinião pública aos excluídos das eleições.

Pela Constituição de 1824 (art. 94, II), nessa linha, os libertos eram inelegíveis. Embora a reforma eleitoral de 1881 tivesse eliminado tal incapacidade política (NABUCO, 2000, p. 16), a nova exigência do saber ler e escrever, como requisito ao alistamento eleitoral, impedia a maioria deles tanto de ser votada quanto de votar.

${ }^{24}$ Entre imprensa política e literária, as fronteiras eram mais tênues que entre cidadania ativa e passiva. vol.10, no. 01, Rio de Janeiro, 2017.pp.494-518 
Isso não evitava, porém, o exercício da liberdade de associação entre libertos, nem sua participação na manifestação da Sociedade 13 de Maio. Possuída "de nobre patriotismo, não deixou que ficasse sepultada no olvido a data que assignala o primeiro passo dado no sentido de libertar-se a nação brazileira", comemorando a 28 de setembro de 1888 a liberdade do ventre conquistada pelo ministério 10 de março, graças à habilidade política de seu presidente, o Visconde do Rio Branco (Gazeta Paranaense, Curityba, 30 set. de 1888, p. 2).

Ao final da tarde, "sahiu ella encorporada da casa em que funcciona, e, ao som de uma banda de musica, ao estrugir de foguetes, e á luz de um esplendido marche aux flambeaux dirigiu-se ao palacio da presidencia", onde "foram erguidos muitos e enthusiasticos vivas! - a S. Ex. [o presidente da província], ao ministerio 10 de Março, a S. A. a Princeza Imperial e a S. M. o Imperador, tocando a banda de musica por essa ocasião o hymno nacional" (Gazeta Paranaense, Curityba, 30 set. de 1888, p. 2). Analfabetos ou não, os libertos participaram de manifestação considerável e, nela, expuseram sua opinião política, inclusive contra o movimento republicano a tomar vulto após a abolição ${ }^{25}$. Ao contrário dos direitos políticos em sentido estrito, os espaços menos formais de manifestação pública eram, se não democráticos, ao menos mais abertos e flexíveis, incluindo demandas inovadoras e alguns cidadãos passivos num cotidiano constitucional fugidio a modelos teóricos.

Por isso, podia-se sentenciar sem tom de surpresa ou novidade, "O publico politico tem um recinto estreito, onde não é permittido nem murmurar". O dos cafés, por outro lado, compunha-se da "gente que levanta e grita" (Gazeta Paranaense, Curityba, 27 jul. de 1888, p. 1), responsável por narrar ao público simples e iletrado as questões prementes. Fazia-o a seu modo: aos gritos e discursos exaltados, entre bicadas na xícara de café, ou goladas no mate chimarrão. Esse tipo de público era "a gazetilha do periodico, a chronica da capital" (Gazeta Paranaense, Curityba, 27 jul. de 1888, p. 1), âmbito de discussão dos acontecimentos grandes e pequenos, públicos e privados. À leitura de jornais e panfletos em voz alta, misturava-se a repetição de boatos e "contos que fazem rir e os que fazem chorar" (Gazeta Paranaense, Curityba, 27 jul. de 1888, p. 1). Espaços abrangendo do flâneur aristocrático ao escravo de ganho (antes do treze de maio), mercearias e tavernas representavam zona informal de discussão pública, permeável à cidadania passiva. Era possível afirmar, nessa linha, "Um grito ousado no meio de um café propaga-se como a luz" (Gazeta Paranaense, Curitiba, 27 jul. de 1888, p. 1), sobretudo graças a certa inclinação social à eloquência, ao "discurso vehemente, arrebatador e scintillante" que, mesmo proferido de improviso, "provocava applausos enthusiasticos" pelo bom manejo da "linguagem de fogo" e pela "presença simpática do popular e venerado orador" (Gazeta Paranaense, Curityba, 3 jan. de 1888, p. 3).

A comparação de fontes eruditas e cotidianas da cultura jurídica, assim, permite apreender a duplicidade da opinião pública. Se no pensamento estreitava o vínculo representativo e estabelecia limites aos poderes

\footnotetext{
${ }^{25}$ Ao sublinhar essa abertura, não pretendo neutralizar as tensões políticas do momento nem a opressão por que haviam passado e ainda passavam os libertos. Em fins do Império, a sociedade agitava-se em movimentos políticos antagônicos. A descrição vol.10, no. 01, Rio de Janeiro, 2017.pp. 494-518 
constituídos, evitando tanto abusos dos governantes quanto excessos populares, no cotidiano constitucional incluía parcelas da cidadania passiva na política constitucional, relativizando a divisão entre direitos civis e políticos por meio da discussão pública. Tratava-se, portanto, não apenas de um meio de fiscalizar governantes e limitar poderes; também de um canal de divulgação de ideários (e.g. republicanismo) e reivindicação de reformas (e.g. abolicionismo e federação), expressando as aspirações de grupos politicamente organizados - alguns deles, como a Sociedade 13 de Maio, compostos majoritariamente por excluídos das eleições.

\section{A RECEPÇÃO DE UMA METÁFORA: FUNDAMENTOS DE UMA SENSIBILIDADE JURÍDICA}

Jeremy Bentham teria sido o primeiro a utilizar o termo Tribunal da Opinião Pública (CUTLER, 1999, p. 325). Apesar de a metáfora do tribunal difundir-se por contextos constitucionais distintos, o rigor sistemático de Bentham torna sua análise única. Como observa Venn Dicey, "Bentham não era, primariamente, um moralista baseado no utilitarismo, nem um filantropo: ele era filósofo do direito e reformista da legislação" (DICEY, 1919, p. 127), decorrendo disso, talvez, a atenção especial a temática tão sensível às constituições políticas. Em Constitutional Code, dedicou não apenas capítulo à noção de autoridade constitutiva; também parágrafo inteiro a seu tribunal, conferindo-lhe centralidade em seu edifício teórico, projetado "ao uso de todas as nações e governos professando opiniões liberais", conforme o subtítulo da obra (BENTHAM, 1830).

Nessa arquitetura logicamente organizada, os poderes dividiam-se em quatro, três constituídos e um constitutivo, nomeado autoridade constitutiva, definida como "aquela pela qual, a todo o tempo, os detentores das diversas outras autoridades neste estado são o que são: por ela, imediata ou mediatamente, eles foram alocados em suas posições, e delas são sempre desalocáveis" ("Bentham , 1830, p. 24). O Tribunal da Opinião Pública representava a autoridade constitutiva na política constitucional, estando a ela submetido como o judiciário ao legislativo (BENTHAM, 1830, p. 33-34)26. Um "funcionário a integrar o Judiciário", esclarecia, "exerce suas funções por alocação expressa - por delegação. Um membro do Tribunal da Opinião Pública as exerce sem delegação; ele não precisa disso" (BENTHAM, 1830, p. 34)27. Qualquer pessoa a tomar parte em questões públicas exercia essa função: tanto o eleitor integrando o corpo constitutivo do estado quanto o indivíduo excluído das eleições por censo ou nacionalidade.

Em On the liberty of the press and public discussion, Bentham se havia colocado na última posição.

transcrita no corpo do texto, na verdade, talvez só tenha sido "digna" das colunas da Gazeta Paranaense por ser estratégica à contrapropaganda conservadora, oposta ao movimento republicano pós-abolição.

${ }^{26}$ Nesse período, o judiciário era o menos significativo dos poderes, enquanto o legislativo detinha a proeminência. Daí a comparação de Bentham entre o Tribunal da Opinião Pública e a autoridade constitutiva, por um lado, e os poderes judiciário e legislativo, por outro. 
Conjunto de cartas escritas com a finalidade de serem publicadas em El Constitucional, "o mais popular, o mais habilmente conduzido e o mais distinto dos jornais diários de Madri" (BENTHAM,1821, p. III) 28 , o escrito tinha o propósito de combater proposta legislativa espanhola de consequências drásticas à liberdade de discussão pública. No prefácio, o autor informava, "o texto fora enviado na esperança do seu chegar àquela capital com tempo suficiente para estar diante do público antes do dia em que a lei proposta, que era seu objeto, chegasse à discussão final" (BENTHAM, 1821, p. III) ${ }^{29}$. A confiança na possibilidade de influenciar os resultados do processo legislativo espanhol era significativa da crença nesse tribunal. Voltado a atribuir responsabilidade pela publicidade dos atos, cabia-lhe operar "como freio à conduta da minoria governante" (BENTHAM, 1821, p. 12) ${ }^{30}$.

No exercício de sua função fiscalizadora, seria, "Ao exercício pernicioso do poder de governo, o único freio; ao benéfico, indispensável suplemento. Governantes hábeis o conduzem; governantes prudentes o conduzem ou seguem; governantes tolos o desconsideram" (BENTHAM, 1830, p. 35) 31. Além dessa, Bentham atribuía outras funções ao tribunal da autoridade constitutiva. Exercia também função executiva, materializada no atribuir ou destituir cargos públicos: ao eleger representantes diretos, ou ao censurar funcionários alocados pelos poderes constituídos. A função sugestiva, de outra parte, voltava-se às propostas de melhorias e reformas, encarnando-se diariamente em propaganda política por meio dos direitos e liberdades pertinentes à discussão pública. Antes de apenas limitar, o Tribunal da Opinião Pública promovia campanhas, divulgava ideários políticos e morais, conduzindo muitas vezes a alterações substanciais da vida pública, como a abolição e o federalismo, no caso do Brasil monárquico ${ }^{32}$.

Sem a função de fornecer evidência, no entanto, como fiscalizar instituições e funcionários, renovar quadros burocráticos, reivindicar reformas? Ante a conduta de qualquer funcionário, a publicidade seria "não apenas moral; também legalmente obrigatória" (BENTHAM, 1830, p. 37) ${ }^{33}$, culminando na atribuição de

\footnotetext{
27 "A functionary belonging to the Judiciary, exercises his functions by express location - by commission. A member of the Public Opinion Tribunal exercises his functions without commission; he needs none." (Tradução livre).

28 "(...) the most popular, the most ably coducted, and the most distinguished of the Madrid daily papers." (Tradução livre).

29 "It [the present Tract] was begun, continued, and ended, for the purpose, and under the full assurance of its being translated into Spanish, and published at Madrid: it was sent in the hope of its reaching that capital, time enough to be before the public, antecedently to the day on which the proposed law [to shut down public discussion], which was the subject of it, would come under final discussion." (Tradução livre).

30 "(...) operates as a check upon the conduct of the ruling few." (Tradução livre).

31 "To the pernicious exercise of the power of government it is the only check; to the beneficial, an indispensable supplement. Able rulers lead it; prudent rulers lead or follow it; foolish rulers disregard it." (Tradução livre).

32 Segundo Joaquim Nabuco (2000. p. 11), "O advento do abolicionismo coincidiu com a eleição direta, e sobretudo com a aparição de uma força, a qual se está solidificando em torno da imprensa - [...] -, força que é a opinião pública." Essa força também promovia a outros ideais políticos, como o federalismo: "Esta politica de descentralisação, esta politica de autonomia, esta politica de federação ou de governo local, chamem-n'a como quizerem", afirmava o senador Dantas, "vai dia a dia ganhando terreno neste Imperio. As provincias de S. Paulo, do Pará, da Bahia, de Pernambuco, de Minas Geraes, do Rio de Janeiro, do Rio Grande do Sul, emfim, quase todas as provincias, pelos meios mais publicos de manifestação, - pela imprensa, pelos meetings, nas assembléas provinciaes, nas representações trazidas aos poderes publicos - todas ellas agitam-se, movem-se em torno desta idéa - de descentralização ou federação". (Annaes do Senado do Imperio do Brazil, sessão em 26 de setembro de 1888, p. 217).

33 "On functionaries, the exercise of the statistic function is not only morally but legally obligatory ( ... )" (Tradução livre).
} vol.10, nº. 01, Rio de Janeiro, 2017. pp. 494-518 
responsabilidade tanto legalquanto moral. Ao Tribunal da Opinião Pública, nessa linha, subjazia uma concepção do ser humano decorrente do utilitarismo por que seu autor é conhecido. Ora, se os "governantes estão, pela natureza inalterável da constituição humana, dispostos a maximizar a aplicação do bem a si mesmos, do mal aos governados $^{\prime \prime 34}$, então, "para tornar a conduta daqueles tendente à maximização da felicidade, não é menos necessário empregar, no caso deles, o instrumento da coerção" (BENTHAM, 1830, p. 14) ${ }^{35}$. Estabelecida a responsabilidade apenas pela certeza do mal (BENTHAM, 1830, p. 15), e incapacitado o legislativo de assegurá-la a todos os casos, caberia ao Tribunal da Opinião Pública aplicar sanção moral àqueles não previstos em lei, a fim de não deixar espaço isento de coerção.

Assim como ao judiciário cabia assegurar os preceitos instituídos pelo legislativo, ao tribunal da autoridade constitutiva competia formar juízos baseados na moral pública. Nesse arranjo utilitarista, a maximização da felicidade seria garantida pela sobreposição de mecanismos de coerção atuando em dois níveis. $\mathrm{O}$ primeiro e menos abrangente centrava-se na sanção legal; o segundo e mais amplo, na moral. Em On the liberty of the press and public discussion, Bentham sublinhava, "Toda expressão indicando desaprovação das estruturas de governo, ou da conduta de qualquer pessoa fazendo parte do exercício dos poderes governamentais, implica em imputação sobre a reputação: sobre a reputação das pessoas à cabeça do governo" (BENTHAM, 1821, p. 11$12)^{36}$. Ao ocupar função pública, o indivíduo expunha-se a discussões, escritos, imagens, colocando à prova seu conceito na sociedade política.

De acordo com o autor, "O funcionário militar é pago para enfrentar o fogo inimigo. O funcionário civil é pago para enfrentar a palavra falada e escrita. O soldado que não encara o campo de batalha é um tipo de covarde. O civil que não se expõe à censura, outro" (BENTHAM, 1830, p. 40) ${ }^{37}$. Continuação da guerra por outros meios, a política constitucional contava com os debates travados no Tribunal da Opinião Pública para a realização da responsabilidade. À luz desse pilar das constituições políticas, deixam-se apreender as alterações ensejadas pela recepção da metáfora no Brasil monárquico. Se em Constitutional Code as responsabilidades legal e moral se deviam complementar na realização de coerção panóptica; no direito público imperial, a responsabilidade moral predominava sobre a legal, sendo esta, "na máxima parte dos casos, uma verdadeira burla" (URUGUAI, 2002, p. 378).

\footnotetext{
34 "(...) rulers are by the unalterable constitution of human nature, disposed to maximize the application of the matter of good to themselves, of the matter of evil to rulees." (Tradução livre).

35 "To render the conduct of rulers conducive to the maximization of happiness, it is not less necessary to employ, in their case, the instrument of coercion, than in the case of rulees." (Tradução livre).

36 "Every expression, betokening disapprobation of the texture of the government, or of the conduct of any person bearing a part in the exercise of the powers of government, conveys an imputation on reputation: on the reputation of the persons at the head of the government." (Tradução livre).

37 "The military functionary is paid for being shot at. The civil functionary is paid for being spoken and written at. The soldier, who will not face musquetry, is one sort of coward. The civilian who will not endure obloquy, is another." (Tradução livre).
} 


\section{A recepção no pensamento constitucional brasileiro}

Ao insistir "na observância desta importante medida constitucional da publicidade mais ilimitada dos atos", Silvestre Pinheiro afirmava ser "o único meio de impedir que a responsabilidade venha a ser ilusória"38, permanecendo fiel à temática da dupla responsabilidade, baseada tanto na coerção legal quanto na moral. Sobre indivíduos ocupando cargos públicos, sublinhava, "há faltas pelas quais podem ser encaminhados às autoridades encarregadas de conhecê-las e infligir a pena decretada pela lei; e há outras que somente pertencem ao tribunal da opinião pública"39. Se às primeiras aplicavam-se institucionalmente as sanções previstas em lei; às segundas não seria contraposta a devida censura sem ampla publicidade, visto "não poderem ser apreciadas pelo público que é seu juiz competente, se os atos do funcionário sobre os quais há de pronunciar sentença não estejam a sua vista". Como se formaria juízo acerca de indivíduo no exercício de cargo público, "senão pela observação constante de toda a sua conduta" (FERREIRA, s./d., p 16) ${ }^{40}$ ?

Embora houvesse semelhanças, o tribunal da opinião pública de Silvestre Pinheiro diferia do originário na relação entre responsabilidade legal e moral. Ao tratar da fiscalização dos atos de altos funcionários, restringia explicitamente a abrangência da sanção legal, ampliando, em contrapartida, a da moralidade. Segundo o autor, nos casos em que "se emite opinião, ou se provoca medida prejudicial aos direitos primitivos da sociedade, ou se usurpa atribuições de outros poderes, sem que o ensaio tenha tido bom resultado, apenas se é responsável ante o

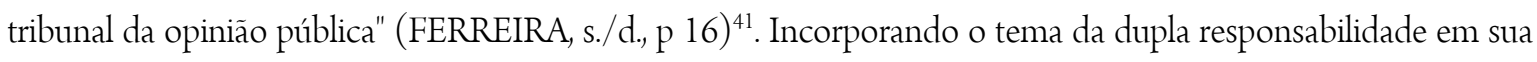
teoria constitucional, Silvestre Pinheiro conferia-lhe sentido adaptado a sua sensibilidade jurídica. As responsabilidades legal e moral já não seriam complementares em todos os casos. Ao sublinhar haverem faltas pertencentes somente ao tribunal da opinião pública, relia a metáfora elaborada em ambiente utilitarista, recepcionando-a em contexto distinto de Constitutional Code.

Nessa dissociação entre as espécies de responsabilidade encontrada no pensamento do teórico

\footnotetext{
38 "No es estraño que insistamos sobre la observancia de esta importante medida constitucional de la publicidad mas ilimitada de los actos de las cámaras; pues la exigimos de todos los actos de los funcionarios públicos, sin excepcion, como único medio de impedir que la responsabilidad venga á ser ilusoria." (Tradução livre).

39 "Los miembros del parlamento nacional, como todos los demas funcionarios públicos, están sujetos á dos especies de responsabilidad; porque hay faltas por las cuales pueden ser llevados ante las autoridades encargadas de conocer en ellas é inflijir la pena decretada por la ley; y hay otras que solo pertenecen al tribunal de la opinion pública." (Tradução livre).

40 "Pero las faltas de la segunda especie no pueden ser apreciadas por el público que es su juez competente, si los actos del funcionario sobre qué há de fallar no están a su vista; porque no puede formarse um juicio imparcial por uno ú otro de estos actos en particular, ni aun por cierto número de ellos tomados á parte, sino por la observacion constante de su conducta entera." (Tradução livre).

${ }^{41}$ Pero si el orador no hace mas que emitir una opinion, ó provocar una medida perjudicial á los derechos primitivos de la sociedad, ó usurpar las atribuiciones de otros poderes, sin que esta provocacion haya tenido un buen resultado, solo es responsable ante el tribunal de la opinion publica." (Tradução livre).
} 
português reside, se não precedente ${ }^{42}$, ao menos chave para interpretar a metáfora do tribunal no direito público brasileiro, caracterizado pela proeminência da moral sobre a legalidade. Autodidatas e bacharéis eloquentes se encarregaram de traduzi-la à sensibilidade da monarquia constitucional brasileira, atuando nos dois grandes alicerces da opinião: a imprensa e a tribuna parlamentar. No trânsito entre uma e outra, a discussão pública consistia numa das manifestações da circularidade da cultura jurídica, como a define Luís Fernando Lopes Pereira (2012, p. 31-53): pensamento forjado ao calor dos debates sedimentava em livro (cotidiano ao erudito) que, por sua vez, realimentava os debates (erudito ao cotidiano). Para melhor apreender a recepção da metáfora no pensamento constitucional brasileiro, nessa linha, convém retomar a discussão pública acerca da responsabilidade pelos atos do poder moderador.

Se consolidou-se em dois livros do Segundo Reinado (Ensaio sobre direito administrativo, do Visconde do Uruguai, e Da natureza e limites do poder moderador, de Zacarias de Góes e Vasconcelos); também deitava raízes em discussões da imprensa e discursos da tribuna. Defendendo a responsabilidade legal e moral dos ministros pelos atos do poder moderador, Zacarias de Góes legava indício dessa origem: "Estava já prestes a publicar-se o pequeno escrito que aí vai - sobre a natureza e limites do poder moderador -, quando a tribuna da Câmara temporária veio a tocar nesse mesmo assunto, de que, havia pouco, a imprensa tão largamente se ocupara" (VASCONCELOS, 1862, p. 21). Ao defender apenas a responsabilidade moral dos ministros, o Visconde do Uruguai (2002, p. 306-337) transcrevia precedentes parlamentares sobre o tema. À retomada da controvérsia em 1860, esclarecia terem contribuído "O Jornal do Commercio, o Regenerador, o Correio da Tarde por um lado; o Correio Mercantil o o Diário do Rio de Janeiro por diverso, além de outros jornais". E continuava, "Essa discussão da imprensa repercutiu na Câmara dos Deputados" (URUGUAI, 2002, p. 334) 3 .

Quanto aos argumentos do debate, Uruguai restringia as atribuições constitucionais do monarca, subtraindo-lhe a prerrogativa exclusiva sobre o executivo, a fim de the garantir a independência da referenda ministerial no exercício do poder moderador. Interpretando os arts. $98^{44}$ e $102^{45}$ da Constituição, o autor do Ensaio ressaltava, "A Constituição distingue formalmente no imperador o primeiro representante e chefe supremo da nação, a quem ela delegou privativamente as atribuições que formam o poder Moderador; e o chefe do poder executivo" (URUGUAI, 2002, p. 350). Segundo sua leitura, o primeiro era delegado privativamente ao imperador, implicando apenas responsabilidade moral dos agentes responsáveis. O segundo, a ele e aos ministros de estado.

\footnotetext{
${ }^{42}$ No Brasil, Silvestre Pinheiro era autor importante. Citam-no tanto Zacarias de Góes e Vasconcelos quando o Visconde do Uruguai, nos livros analisados adiante. Entre "As obras e escriptos, de que nos auxiliamos em nosso trabalho", ademais, São Vicente elenca o Curso de direito publico, de Silvestre Pinheiro. (PIMENTA BUENO, 1857, p. 17).

${ }^{43}$ Para maiores detalhes sobre as origens cotidianas dessas fontes eruditas da cultura jurídica, cf. LOBO; STAUT JÚNIOR, 2015.

${ }^{44}$ Constituição do Império do Brazil: "Art. 98. O Poder Moderador é a chave de toda a organisação Politica, e é delegado privativamente ao Imperador, como Chefe Supremo da Nação, e seu Primeiro Representante, para que incessantemente vele sobre a manutenção da Independencia, equilibrio, e harmonia dos mais Poderes Politicos."
} 
Por isso, apenas os atos do executivo dependeriam da referenda para produzir efeitos. Pelas consequências, seriam responsáveis os ministros moral e legalmente.

Zacarias de Góes, por sua vez, respondia esse argumento com recurso à reductio ad absurdum. Ante o art. $99^{46}$ da Constituição, conduziria à irresponsabilidade pelos atos do poder moderador, verdadeiro insulto aos princípios do sistema representativo. $\mathrm{O}$ autor insistia, afinal, na inviolabilidade legal e moral da figura régia. Para garanti-la, convinha à coroa estar coberta por todos os lados, não podendo haver ato seu sem garantia da responsabilidade de outrem. Se a assumiam os conselheiros de estado pelos conselhos ${ }^{47}$, a fortiori a deveriam assumir os ministros pela execução. Ainda que a constituição não fosse expressa quanto à responsabilidade ministerial pelo exercício da prerrogativa régia, seria absurdo punir os conselheiros pelas consultas e resguardar os ministros pela execução das decisões.

Ao fundamentar sua posição, Zacarias de Góes ampliava as atribuições constitucionais do imperador, a quem a constituição teria delegado privativamente tanto o poder moderador quanto o executivo. Em ambos os casos, os atos seriam exercidos por meio dos ministros. "Se não dependem de referenda, se os ministros são totalmente estranhos a esses atos, então não são responsáveis legal nem moralmente", afirmava Zacarias de Góes. E ironizava a interpretação do adversário, "O direito desconhece o que seja responsabilidade de pura cortesia". De outra parte, se "dependem de referenda, tem lugar a responsabilidade não só moral, mas legal, não só de censura, mas de pena, qual no caso couber" (VASCONCELOS, 1862, p. 128).

Afirmando ser exclusivamente moral a responsabilidade aplicável aos atos do poder moderador, no entanto, Uruguai tomava por fundamento a política constitucional brasileira. Nela, consistia a "responsabilidade legal, na máxima parte dos casos, [em] uma verdadeira burla. Ainda não tivemos um ministro condenado, durante os 35 anos que temos de governo representativo", podendo-se concluir, "ou que a responsabilidade penal é ineficaz, ou que tudo correu sempre entre nós às mil maravilhas" (URUGUAI, 2002, p. 378). Apesar de irresponsáveis perante a lei, ministros e monarca ainda exporiam suas reputações à censura, pois havia "uma espécie de responsabilidade chamada moral ou censura imposta pela opinião pública, em muitos casos mais eficaz do que a legal". E continuava, "Não há soberano, por mais poderoso, que não a tema, porque ela mina e destrói a força moral, sem a qual não pode durar um poder" (URUGUAI, 2002, p. 377).

Por mais que Zacarias de Góes e Vasconcelos (1862, p. 130) tenha criticado essa posição por fidelidade a "um princípio, cuja falta importaria uma lacuna extraordinária em nossa forma de governo", não escapava a seu

\footnotetext{
${ }^{45}$ Constituição do Império do Brazil: "Art. 102. O Imperador é o Chefe do Poder Executivo, e o exercita pelos seus Ministros de Estado."

${ }^{46}$ Constituição do Império do Brazil: "Art. 99. A Pessoa do Imperador é inviolavel, e Sagrada: Elle não está sujeito a responsabilidade alguma."

${ }^{47}$ Constituição do Império do Brazil: "Art. 143. São responsaveis os Conselheiros de Estado pelos conselhos, que derem, oppostos ás Leis, e ao interesse do Estado, manifestamente dolosos."
} 
tempo e contexto. Mesmo para ele, a coerção prevista em lei não consistia em solução sempre desejável. Pelo contrário, seus defensores teriam "por certo que a responsabilidade moral em regra é suficiente para chamar o poder à órbita de seus deveres". A "censura tende", afinal, "a prevenir os delitos e a dispensar a imposição de penas que só terão de aplicar-se em casos mais graves e extraordinários" (VASCONCELOS, 1862, p. 130). E acrescentava, "estando o delito já cometido, mais importa muitas vezes precipitar o ministro do poder, mediante a divulgação e censura do seu procedimento, do que promover-lhe processo e castigo" (VASCONCELOS, 1862, p. 67). Segundo seu defensor, portanto, a responsabilidade legal deveria ser aplicada excepcionalmente, pois "não há quem duvide que é sempre melhor prevenir do que ter de castigardelitos" (VASCONCELOS, 1862, p. 73).

O debate analisado permite tangenciar a releitura brasileira da metáfora em questão, expressa na síntese de São Vicente, "A opinião publica é o tribunal da responsabilidade moral" (PIMENTA BUENO, 1857, p. 338). Marcada por continuidades com passado e tradição, a sensibilidade jurídica vigente recepcionou a opinião pública à luz das virtudes cristãs de que se compunha a força moralmencionada por Uruguai. Essa influência teológicomoral, no entanto, não se deixa apreender claramente em indícios eruditos da cultura jurídica. Apesar de mais elegantes e refinados, são menos ricos em detalhes e circunstâncias relevantes à compreensão do passado. Para compreender melhor a recepção da metáfora, portanto, é necessário descer ao cotidiano constitucional.

\section{A recepção no cotidiano constitucional}

Ao circular na discussão pública, a cultura jurídica trazia à imprensa diária a metáfora em análise, ainda que nem sempre com a afinação e clareza das fontes eruditas. Comemorando seu décimo segundo aniversário, o órgão do partido conservador paranaense ressaltava, "o apoio que temos merecido do publico [...], sobre ser a sentença que aceitamos, é a mais consoladora recompensa deste arduo e ingrato trabalho (...)" (Gazeta Paranaense, Curityba, $1^{\circ}$ jan. de 1888, p. 1). A Gazeta associava sua estabilidade a sentença da opinião pública, obtida pelo desempenho do papel de "representar nossa vida social e politica". Nunca teria deixado "a redacção desta folha", afinal, "de tratar, consoante as suas forças, de todos aquelles problemas a que se achão ligados os mais legitimos interesses da provincia, e de cuja solução depende nosso engrandecimento futuro" (Gazeta Paranaense, Curityba, $1^{\circ}$ jan. de 1888 , p. 1).

Em raro caso de lucidez teórica, o órgão do partido liberal paranaense destacava o "difficil, laborioso, incessante, glorioso encargo" da imprensa na política constitucional. "Na ausencia das autoridades supremas, que [no Brasil] se expressam pelo poder majestatico e corpo legislativo", esclarecia, "a imprensa é o orgão legitimo da opinião, é uma magistratura que crearam os costumes e sanccionou o continuo [ilegível] das populações a seu tribunal" (Dezenove de Dezembro, Curityba, 18 jan. de 1888, p. 3). Associando-se a ela, o Dezenove de Dezembro sublinhava, "A opinião popular ou tacita ou expressa, é o supremo juiz das causas publicas", cabendo- 
lhe "aceital-as se são bôas, recusal-as, fulminal-as, reagir contra elas, se são iniquas, se são más" (Dezenove de Dezembro, Curityba, 3 mar. de 1888, p. 2).

Apesar das diferenças de tom e partido, ambos se diziam órgãos legítimos da opinião, dos mais legítimos interesses da província. Desse vínculo com a autoridade constitutiva, derivaria sua competência para atuar como tribunal da opinião pública, cuja relevância à época convém não menosprezar. Aos "funccionarios que tivessem verdadeira noção da sua responsabilidade perante o publico e zelassem a sua reputação", uma censura gerava o dever de dar-se "pressa em apresentar cabal justificação, fazendo-a logo publicar assim como publicada foi a accusação" (Dezenove de Dezembro, Curityba, 24 nov. de 1888, p. 1). Naqueles tempos, era admirável a importância atribuída aos juízos desse tribunal radicado nos preceitos morais vigentes. Como testemunhava uma coluna de curiosidades, "Eu e você, somos muito reverentes para com a opinião publica, da qual esperamos um juizo que nos abone no conceito geral da sociedade" (Dezenove de Dezembro, Curityba, 13 out. de 1888, p. 1).

À relevância do tribunal da responsabilidade moral, correspondia a desvalorização da legalidade. Assim como no debate entre Zacarias de Góes e Uruguai, no cotidiano a responsabilidade moral não complementava, mas entrava em conflito com a aplicação das leis tanto na grande quanto na pequena política constitucional. Em sessão legislativa de 19 de julho de 1888, a assembleia provincial do Paraná instaurou processo fundado na legislação vigente, visando a sancionar fraudes eleitorais (Dezenove de Dezembro, Curityba, 20 jul. de 1888, p. 12). Não ficou sem censura "a ficticia responsabilidade promovida pelos liberaes" (Gazeta Paranaense, Curitiba, 7 nov. de 1888, p. 3). Eleitores reunidos em manifestação pública, "precedidos da excellente banda musical - Lyra dos Campos Geraes, de grande concurso de povo e sob o estrugir de uma foguetada extraordinaria", manifestaram a sua indignação contra "o procedimento inqualificavel da Assembléa Provincial" ( Gazeta Paranaense, Curitiba, 15 nov. de 1888, p. 1): aplicar as penas da lei.

Absolvidos os acusados pelo tribunal do júri - outro espaço de manifestação da opinião pública -, estrugiam "centenas de foguetes, cujos estalidos multiplices esposavão os sons harmoniosos da Lyra dos Campos Geraes". A isso, seguiu-se "um profuso e delicado copo d'agua, durante o qual trocárão-se, entre os cavalheiros presentes, diversos toasts", terminando em brinde "levantado pelo orador official em um bellissimo, vehemente e electrisador speech". À luz da sensibilidade vigente, o ato foi compreendido como "perseguição movida por um partido, que de liberal só tem o rotulo" (Gazeta Paranaense, Curitiba, 15 nov. de 1888, p. 1). Ao perseguir o adversário vencido, os liberais se mostrariam capazes dos atos mais "cavillosos, trahiçoeiros e vingativos para com os que lhes são desaffectos e não comungão de suas idéas" (Gazeta Paranaense, Curitiba, 15 nov. de 1888, p. 2).

Além de ter de castigar, aplicar as penas da lei consistia em perseguir o adversário. Essa incompatibilidade entre responsabilidade moral e legal decorria dos valores constituintes da sensibilidade jurídica. Sem pretender descrição exaustiva, convém analisar seus principais aspectos recorrendo ao ideal de homem público constante 
em necrologias: no Brasil, a morte produz o efeito de idealizar os finados ${ }^{48}$. De importante político paranaense ${ }^{49}$, assim, destacavam-se "todas as raras virtudes que estrellavam aquella alma varonil e nobre, feita de todas as heroicidades dos Gracchos e todas as bondades de Jesus" (Gazeta Paranaense, Curityba, 12 jun. de 1888, p. 2). A referência aos Gracos remetia à cultura jurídica eloquente, inspirada em oradores e tribunos clássicos; aquela a Jesus, à tradição religiosa, inspirada em virtudes cristãs e economia da graça (HESPANHA, 2010, p. 85-109): benevolência, caridade, perdão.

A "alma ridente, sempre aberta ás mais santas emoções, forte e expansiva na amizade, edificada para a caridade e todas as virtudes christãs" (Dezenove de Dezembro, Curityba, 25 abr. de 1888, p. 2), era o que se destacava de outra personagem, menos envolvida na grande política. Dessa figura mais vinculada à tradição, de que se nutriam as raízes morais da opinião pública, mesmo o adversário republicano dizia, "A caridade era o apanagio do coração desse grande homem; não havia dôr que batesse á sua porta, á qual elle não proporcionasse todo o lenitivo possivel". E continuava, "Membro distincto de uma familia respeitavel e elevada da nossa sociedade", seria "despido da menor vaidade; d' ahi, e dos beneficios que largamente espalhava, a sua popularidade, consagrada pela estima de seus concidadãos" ( $A$ Republica, Curityba, 27 abr. de 1888, p. 1). A oposição conservadora não deixava por menos, "pela fortaleza inexpugnavel de suas virtudes, alcançou as maiores culminancias sociaes e politicas" (Gazeta Paranaense, Curytiba, 23 nov. 1888, p. 2).

Recepcionada no Brasil monárquico, a opinião pública imbuiu-se desse espírito teológico, assim como as figurações político-constitucionais em que se realizava. Ao ideal fundado em virtudes cristãs, correspondia o perfil da imprensa e seus redatores. Se a ela cabia produzir "as revoluções do pensamento, a evolução das idéas, a civilização dos povos, a repressão dos despotismos, a guia das nações, a alavanca de todas as grandes e utilitarias transformações" ( Gazeta Paranaense, Curityba, 4 jan. de 1888, p. 1), cumpria-lhe fazê-lo nos limites traçados pela constituição moral. Por isso, "Os imperadores, os reis e os presidentes das republicas, acolhendo com affabilidade os discipulos de Guttenberg, comprehenderam que a verdadeira imprensa nunca seria flagello para os poderes emanados dos povos, e para a religião, que provem de Deus" (Gazeta Paranaense, Curityba, 4 jan. de 1888, p. 1). Representando o extremo radical da opinião, mesmo ao jornal $A$ Republica convinha "manter[-se] serio e moralisado", finalidade a que se sacrificava o "sempre dedicado e honesto" Dr. Mendes Gonçalves, responsável pelo periódico (Dezenove de Dezembro, Curityba, 14 ago. de 1888, p. 3).

\footnotetext{
48 "Uns e outros ampliavam a realidade, inventavam detalhes, atribuíam-lhe casos e aventuras, a lenda de Vadinho começava a nascer ali junto de seu corpo, quase na hora mesma de sua morte. O citado doutor Giovanni Guimarães imaginava pedaços inteiros de histórias, floreava os acontecidos, era chegado a uma mentirazinha bem apoiada em datas e locais precisos." (AMADO, 2001, p. 16).

${ }^{49}$ Para afastar a eventual objeção de que os elogios fúnebres paranaenses nada diriam sobre o ideal brasileiro de homem público, convém mencionar que o importante político citado, Eufrásio Correia, era um político de envergadura nacional, de forma que os epitáfios afluíram de todo o Brasil, permitindo generalizar o argumento. Cf., nesse sentido, Gazeta da Tarde, Côrte, 4 fev. de 1888, p. 2 e Gazeta de Noticias, Côrte, 5 fev. de 1888, p. 1, para citar dois exemplos do Rio de Janeiro, então capital do Império.
} vol.10, no. 01, Rio de Janeiro, 2017.pp.494-518 
Não seria vantagem a partido algum, afinal, se seu órgão tomasse "lugar saliente na rara classe dos Corsarios do jornalismo" (Dezenove de Dezembro, Curityba, 14 ago. de 1888, p. 3). Por isso, ante a possibilidade de "proceder a critica severa e crua da personalidade" do adversário político por ter "a vista livre das illusões causadas pela amisade", o autor da coluna Marmota sublinhava que fazê-lo num momento em que ainda estavam frescas as cinzas do finado, e ainda se derramavam lágrimas por seu desaparecimento, "seria a manifestação da falta d'esta piedade que sentimos pelos nossos proprios inimigos quando elles tombam na estrada, uma das virtudes esta mais communs no coração humano e uma das mais consolativas que existem" ( $A$ Republica, Curityba, 15 mar. de 1888, p. 2). A coluna era satírica, e seu autor, anônimo: a força normativa das virtudes cristãs transformava água em vinho.

Antes de pertencer a indivíduos e instituições excepcionais, essas virtudes constituíam um ideal normativo difuso na sociedade brasileira da época, como indicam os versos constantes na Constituição moral do Visconde de Cairu moralista:

Com o suor de meu rosto o pão grangeio,/ Alegre trabalhando em lida honesta:/ Da consciencia a voz me manifesta/ Quando a Virtude he bella, o Vicio he feio./ A ninguem faço mal; o bem que posso/ (Fé, e esperança em Deos) á todos faço./ Da Patria ao Comum Voto satisfaço./ Da Lei da Natureza eis breve esboço! (LISBOA, 1824, p. 157).

Coroado de virtudes cristãs, esse ideal consistia em sintoma da permanência de preceitos teológicomorais no âmbito da política constitucional. Essa sensibilidade jurídica atrelada à tradição religiosa conduzia ao caráter, se não imoral (perseguir o adversário), ao menos indigno (ter de castigar) de aplicar as penas da lei, culminando na tensão entre responsabilidade moral e legal. Daí a importância admirável atribuída aos juízos da opinião pública. Restringindo a eficácia da legalidade, tal sensibilidade ampliava a competência do tribunal da responsabilidade moral. Ao lado de disputa política, dependência do estado e perfil eloquente do jurista, ela consistia numa das principais razões pelas quais, nos tempos da monarquia constitucional, escrevia-se sem problemas "contra o monarcha, contra o governo, contra as autoridades" (Gazeta Paranaense, Curityba, 12 jul. de 1888, p. 2). Segundo testemunho da época, essa liberdade "só exist[ia] em nosso paiz!" (Gazeta Paranaense, Curityba, 14 jul. de 1888 , p. 2$)^{50}$. Ela expressava os fundamentos de uma sensibilidade jurídica particular.

\section{CONCLUSÃO}

Ao problema proposto, pode ser oferecida a seguinte resposta: assim como sistema representativo e separação dos poderes, opinião pública é uma categoria das constituições políticas, consistente em responsabilidade pela publicidade dos atos. No ideário constitucional da época, ela estreitava o vínculo representativo e estabelecia limites aos poderes constituídos. Imputava censura à reputação ao realizar-se num complexo de figurações político-constitucionais, como imprensa, tribuna parlamentar e demais espaços de 
discussão pública. Neles, manifestava-se sua duplicidade: se estabelecia limites aos poderes constituídos, a opinião consistia também em canal de demandas inovadoras.

À história do direito, a definição exposta possui relevância teórica e metodológica. Ao por em evidência um de seus alicerces menos conhecidos, por um lado, descortina um novo horizonte de compreensão sobre as constituições políticas, focando seu viés dinâmico e a importância da discussão pública para a arquitetura constitucional do séc. XIX. Por outro lado, a citada definição permite enquadrar atas parlamentares, artigos de jornal e demais fontes vinculadas à discussão pública como indícios de uma realidade tipicamente históricojurídica. Esse modelo metodológico permite analisar questões pertinentes à história política, constitucional e da cultura jurídica (eloquente), assim como apreender as particularidades de determinado momento histórico: umas e outras circulam na discussão pública.

Essa definição também traz contribuições a uma teoria constitucional interessada no resgate da densidade política das constituições (CHUEIRI, 2013, p. 25-36; GARGARELLA, 2015, p. 41-65). Essencialmente político, o constitucionalismo do séc. XIX tem fundamentado reflexões contemporâneas (GARGARELLA, 2014), voltadas à abertura da política constitucional (a sala de máquinas da constituição) à participação democrática. Quanto melhor conhecido, maior o impacto de seu exemplo na formulação de novas perspectivas. E a noção de opinião pública exposta neste trabalho parece ter muito a contribuir nesse sentido, especialmente num período em que novas formas de comunicação e humor minam o monopólio dos meios comunicacionais e aproximam o grande público da alta política constitucional. Talvez uma das portas de acesso à sala de máquinas da constituição consista justamente nesses novos meios de manifestação da opinião pública.

Os acontecimentos recentes na política constitucional brasileira, ademais, indicam não pertencer a tensão entre responsabilidade moral e legal a um passado distante que é preciso superar. Pelo contrário, trata-se de uma realidade presente que seria interessante avaliar à luz da história. Apesar das inúmeras transformações econômicas, sociais e jurídicas ao longo de quase treze décadas, aspectos da moral tradicional e religiosa insistem em despontar na cena política: bancadas religiosas cada vez mais influentes no legislativo (e no governo), representantes justificando seus votos com recurso a família e valores tradicionais, um processo de impeachment baseado no descontentamento e, segundo alguns juristas, sem lastro na legalidade. Embora de forma modesta e mediada, portanto, este trabalho pode contribuir com a discussão política e constitucional contemporânea, se não como fundamento, ao menos como fonte de inspiração.

Quanto à metáfora do tribunal, a análise de sua recepção na monarquia constitucional brasileira permitiu apreender a passagem do Tribunal da Opinião Pública ao tribunal da responsabilidade moral. À luz da sensibilidade jurídica vigente, a opinião pública havia passado por processo de tradução e adaptação a ideário

${ }^{50}$ Para maiores detalhes sobre a liberdade de expressão existente no período, Cf. LOBO; CAPELOTTI, 2014, p. 150-175. vol.10, nº. 01, Rio de Janeiro, 2017.pp. 494-518 
radicado em virtudes cristãs, que dissociou a responsabilidade moral da legal. E isso tanto no caso da responsabilidade pelos atos do poder moderador quanto nas disputas cotidianas da política constitucional. Antes de privilégio da coroa, a tese de Uruguai expressava a sensibilidade jurídica de seu tempo, em que aplicar as penas da lei consistia, se não em perseguir, ao menos em ter de castigar. Assim como o anão teológico de Benjamin ${ }^{51}$ - só não tão pequena nem feia ainda -, a teologia moral animava o autômato da opinião pública. Eis um exemplo de encontro entre constituição, moral e política, remetendo novamente à teoria e à história constitucional.

Em termos metodológicos, por fim, a recepção analisada não teria sido plenamente apreendida por fontes cultas da cultura jurídica, embora a presença delas seja marcante ao longo do texto. Pertencentes ao âmbito erudito, os livros sinalizavam o caminho da recepção. Para percorrê-lo, porém, seria incontornável caminhar por seu pavimento cotidiano. Aos sinais sintomáticos, mas nem sempre conclusivos, convinha associar provas obtidas em pesquisa indiciária, capazes de atribuir força ao argumento historiográfico. $\mathrm{O}$ arcabouço probatório, assim, consiste no diferencial deste estudo: atesta que o desinteresse não reside no período investigado, mas no olhar de alguns intérpretes, conformado por concepções do direito e da história desatentas à complexidade do passado.

\title{
WHAT IS PUBLIC OPINION? STUDY ON BRAZILIAN CONSTITUTIONAL HISTORY
}

\begin{abstract}
In the prism of constitutional history, this essay aims to solve the following problem: what is public opinion? Through the analysis of original evidences it reaches a relevant solution to both the theory and the history of political constitutions, without neglecting a deep understanding of the Brazilian constitutional monarchy. Once received in this context, public opinion embodied characteristics of a particular legal sensibility, in which lawfulness was in sharp contrast to moral duties (charity, forgiveness, benevolence) coming from religious tradition.
\end{abstract}

Keywords: Public Opinion; Moral Responsibility; Political Constitution; Constitutional History; Brazilian Constitutional Monarchy.

\footnotetext{
51 "Sabe-se que teria havido um autômato, construído de modo a responder a cada jogada de um enxadrista com uma contrajogada, capaz de assegurar-lhe a vitória da partida. Uma marionete em trajes turcos, à boca um narguilé, sentava em frente ao tabuleiro situado sobre uma mesa espaçosa. Por meio de um jogo de espelhos, criava-se a ilusão de que essa mesa seria transparente por todos os lados. Na verdade, escondia-se dentro dela um anão corcunda, mestre no jogo de xadrez, que manejava as mãos da marionete com cordões. Pode-se imaginar uma contrapartida filosófica desse mecanismo. A marionete denominada 'materialismo histórico' ganharia sempre. Ela pode disputar sem problemas com qualquer um, se tomar a seu serviço a teologia, hoje reconhecidamente pequena e feia, sendo-lhe, de qualquer forma, proibido expor-se ao olhar." Tradução livre. BENJAMIN, Walter. Über den Begriff der Geschichte. Disponível em: «http://www.mxks.de/files/phil/Benjamin.GeschichtsThesen.html». Acesso $\mathrm{em}: \ll 10 / 01 / 2014 »)$.
} 


\section{FONTES}

A Republica, Curityba, 1888.

Dezenove de Dezembro, Curityba, 1888.

Gazeta Paranaense, Curityba, 1888.

BENTHAM, Jeremy. Constitutional code; for the use of all nations and all governments professing liberal opinions. London: Robert Heward, 1830.

On the liberty of the press and public discussion. London: Willian Hone, 1821.

CONSTANT, Benjamin. Cours de politique constitucionnelle. Paris: Librairie de Guillaumin, 1872.

De la liberté des anciens comparée à celle des modernes. Disponível em: http://www.panarchy.org/constant/liberte.1819.html». Acesso em: «01/08/2014».

FERREIRA, Silvestre Pinheiro. Breves observações sobre a Constituição da Monarchia Portugueza. Paris: Rey e Gravier, 1837.

Compendio de derecho publico interno y externo. Lima: Aurelio Alfaro, s/d.

LISBOA, José da Silva. Constituição moral e deveres do cidadão com exposição da moral pública conforme o espírito da Constituição do Império. Rio de Janeiro: Typographia Nacional, 1824.

NABUCO, Joaquim. O abolicionismo. São Paulo: Publifolha, 2000.

PIMENTA BUENO, José Antonio. Direito publico brazileiro e analyse da Constituição do Imperio. Rio de Janeiro: J. Villeneuve, 1857.

VASCONCELOS, Zacarias de Góes e. Da natureza e limites do poder moderador. Brasília: Senado Federal, 1978.

URUGUAI, Visconde do. Visconde do Uruguai. São Paulo: Ed. 34, 2002.

\section{REFERÊNCIAS BIBLIOGRÁFICAS}

BENJAMIN, Walter. Über den Begriff der Geschichte. Disponível em: «http://www.mxks.de/files/phil/Benjamin.GeschichtsThesen.html». Acesso em: «10/01/2014».

CARVALHO, José Murilo. A construção da ordem: a elite política imperial. Teatro de sombras: a política imperial. $7^{7}$ ed. Rio de Janeiro: Civilização Brasileira, 2012.

CHUEIRI, Vera Karam de. Constituição radical: uma ideia e uma prática. Revista da Faculdade de Direito UFPR, Curitiba, n. 58, p. 25-36, 2013.

CUTLER, Fred. Jeremy Bentham and the Public Opinion Tribunal. The Public Opinion Quarterly, Vol. 63, No. 3 (Autumn, 1999).

DICEY, A. V. Lectures on the relation between law \& public opinion in England during the nineteenth century. 
London: MacMillian and Co., 1919.

ELIAS, Norbert. A sociedade dos indivíduos. Rio de Janeiro: Jorge Zahar Ed., 1994.

FIORAVANTI, Maurizio. Constituzionalismo: percorsi della storia e tendenze attuali. Bari: Laterza, 2009.

GARGARELLA, Roberto. Interpretation and democratic dialogue. Revista da Faculdade de Direito - UFPR, Curitiba, vol. 60, n. 2, 2015, p. 41-65.

La sala de máquinas de la Constitución. Dos siglos de constitucionalismo en América Latina (18102010). Buenos Aires: Katz, 2014.

GEERTZ, Clifford. O saber local: novos ensaios em antropologia interpretativa. Petrópolis: Vozes, 2013.

GINZBURG, Carlo. Mitos, emblemas, sinais: morfologia e história. São Paulo: Companhia das Letras, 1989.

HESPANHA, António Manuel. As outras razões da política: a economia da "graça". In: HESPANHA, António Manuel. A política perdida: ordem e governo antes da modernidade. Curitiba: Juruá, 2010.

Cultura jurídica europeia: síntese de um milênio. Florianópolis: Fundação Boiteux, 2005.

Imbecillitas. As bem-aventuranças da inferioridade nas sociedades de Antigo Regime. São Paulo: Annablume, 2010.

HOLANDA, Sério Buarque de. O Brasil monárquico, v. 7: do Império à República. 7a ed. Rio de Janeiro: Bertrand Brasil, 2005.

LOBO, Judá Leão; PEREIRA, Luís Fernando Lopes. A imprensa do Segundo Reinado no processo políticoconstitucional: força moral e opinião pública. Revista da Faculdade de Direito UFPR, vol. 59, n. 1, p. 179-206, 2014.

LOBO, Judá Leão; STAUT JÚNIOR, Sergio Said. Discussão pública e formação da cultura jurídica: contribuição metodológica à história do direito brasileira. Revista Quaestio Iuris, vol. 08, nº. 03, Rio de Janeiro, p. 1688-1710, 2015.

LOBO, Judá Leão; CAPELOTTI, João Paulo. Humor e liberdade de imprensa em O Mequetrefe. Revista Direito e Práxis, Rio de Janeiro, v. 5, n. 9, p. 150-175, 2014.

LYNCH, Christian Edward Cyril. Monarquia sem despotismo e liberdade sem anarquia: o pensamento político do Marquês de Caravelas. Belo Horizonte: Editora UFMG, 2014.

PEREIRA, Luís Fernando Lopes. A circularidade da cultura jurídica: notas sobre o conceito e sobre método. In: FONSECA, Ricardo Marcelo. Nova história brasileira do direito: ferramentas e artesanias. Curitiba: Juruá, 2012, p. 31-53.

PETIT, Carlos. Discurso sobre el Discurso: oralidad e escritura en la cultura jurídica de la Espanã liberal. Huelva: Universidad de Huelva, 2000.

Trabalho enviado em 17 de maio de 2016

Aceito em 24 de julho de 2016. 